\title{
Sustainable Multimedia with Beta Wave Learning in Letter Literacy to the Achievement of Pupils with Learning Disabilities in Level One Primary School
}

\author{
Yeap. T. W, Salleh Abd Rashid \\ Universiti Malaysia Perlis \\ Kangar, Perlis, MALAYSIA \\ Universiti Malaysia Perlis \\ yeapteikwei@gmail.com
}

\author{
Nazeri Mohammad \\ Institute of Teacher Education Perlis Campus \\ Ministry of Education Malaysia \\ Kangar, Perlis, MALAYSIA \\ nazerincs@gmail.com
}

\begin{abstract}
This study aims to measure the effects of Multimedia with Beta wave in letter literacy to the achievement of pupils with learning disabilities in level one of Malaysian primary school. This research designed using Quasi-experimental method. There were 34 respondents selected as the study sample in Sekolah Jenis Kebangsaan Cina (SJKC) in Perlis area North Malaysia. This study with 34 respondents would be treated with intervention of Simulation Beta Wave Green Technology in six weeks period and without any controlled sample treatment group - A cognitive test was used to collect data after the study intervention was done. Amidst that, the pre and post-test achievement tests carried out after intervention of Multimedia Simulation Beta wave Green Technology. The findings of this study will be analyzed using SPSS19 with descriptive in mean, frequency, $\%$ and $T$-test. The finding of this study show that Multimedia with Beta Green Technology acts as a stimulant cure and gives positive impact on learning achievement in alphabet literacy of Year-One pupils
\end{abstract}

Keywords—-learning disabilities level one, achievement

\section{INTRODUCTION}

Transformation progress of hi-tech education has been implement in whole Malaysia to international level, announcement of YAB Menteri through RTM on 29 September 2015. This innovation is aimed to improve the education quality especially for the groups of learning disabilities pupils. The material fact by Abdul Rasid Jamian, Norhashimah Hashim dan Shamsudin Othman (2009) shows that education degree retrogression has bring many negative impacts.

\section{Problem Statement}

Teachers are blamed by parents and community when the children get weak results in examination. In fact, the main factor lead to the good performance, which is clearly put forward is the success and effectiveness of knowledge transfer by emphasizing on view and write skill, listen and write skill. The fundamental purpose of this research is to investigate how the Beta Wave Learning helps in the literacy achievement in Malay Language, of Year One pupils

\section{A. Research Objectives}

Quantitative research is to prevent and improve the shortcomings that may faces in real. Research activities such as participation observation and interviewing are examined in details (Glesne, C., \& Peshkin. 1992), by simulated the Beta Wave Learning in the process of literacy study in Malay Language, of Year One pupils with learning disabilities (stated as "Pupils"). Generally, this research is to:

1) Identify the needs of Beta Wave Learning in helping Pupils master the listen and write skill in Level One of Malay Language,

2) Identify the needs of Beta Wave Learning in helping Pupils master the look and write skill in Level One of Malay Language,

3) Identify how Beta Wave Learning helps in solving study problems and improving effectiveness of knowledge transfer for Year One Pupils.

\section{B. Research Issue}

This research is to answer following questions: What levels of support that Beta Wave Learning can provides to help Pupils in the achievement of Level One of Malay Language.

1) What levels of support that Beta Wave Learning can provides to help Pupils master the listen and write skill in Level One of Malay Language,

2) What levels of support that Beta Wave Learning can provides to help Pupils master the look and write skill in Level One of Malay Language,

3) Identify what levels of support that Beta Wave Learning can provides to help in solving study problems and improving effectiveness of knowledge transfer for Year One Pupils. 


\section{RESEARCH SIGNIFICANCE}

Wish to provide the results of research to:

1) Teacher Education Division, Ministry of Education Malaysia

2) Institute of Teacher Education Malaysia

3) Ministry of Education Malaysia

4) Minimize the amount of LINUS student

\subsection{Research Theory}

This research complied with Model ADDIE (Moledda, et al., 1996) for the creation of power point teaching system with using the simulation of Beta Wave Learning, which includes early-stage observation, objectives determination, materials election, creation of Malay Language teaching system with multimedia materials and the comparison between Pre and Post outcomes. This is to examine the effectiveness of Beta Wave Learning in helping the achievement of Pupils in Level One of Malay Language. This is very important because the success of research (use of Beta Wave Learning, frequency of $12 \mathrm{~Hz}$ to $40 \mathrm{~Hz}$ ) will lead to a simple and low cost system, to help and focus on the teaching for Pupils, who failed Construct 1 and Construct 2 (C1C2) examinations.

\section{RESEARCH METHODOLOGY}

This research focus on the results of Beta Wave Learning helps Pupils in the literacy achievement. This part will explain on the methods used in the research, improvement measure, research instrument, research population and strategy, data collection methods, and research analysis SPSS19.

\section{A. Research Design}

This research is leading by Quasi-Experimentation (Campbell \& Stanley, 1963) which having separate sections such as pretest-posttest nonequivalent group design. This research did not consist of any controlled candidates as all of them are those who failed the Construct 1 and Construct 2 (C1C2) examinations. The research design will be drawn in Picture 1.

\section{$\mathrm{O} 1$}

$$
\mathrm{X}^{*}
$$

$\mathrm{O} 2$

Picture 1: Quasi-Experimentation (Pretest-Posttest non-equivalent group design)

Notes:

$\mathrm{X}^{*}$ - using Multimedia Simulation Beta Wave Learning in teaching literacy of Malay Language for six week

O1- Pre-Test

\section{O2-Post-Test}

\section{B. Samples}

Research candidates study reading skill for Level One of Malay Language with using Beta Wave Learning, while Construct 1 and Construct 2 examinations used to test the candidates achievement (Sabaria, 2003; Gay and Airasan, 2003). 34 students from Chinese Primary School in Perlis (Northern area of Malaysia) have been chosen as the respondents of this research. They have teaches by using Beta Wave Learning for 6 weeks' time. Pre-Test of Construct 1 and Construct 2 examination had been given to them before teaching with Beta Wave Learning, and Post-Test after that. The examinations are compare and analyze and by using SPSS19 and T-test system. The result shows that Beta Wave Learning bringing positive impacts and improvement in the literacy study in Level One of Malay Language.

\section{Study limitations}

The study excluded the group who has disabilities, hearing, seeing and only for the first year of primary school level and the only students who pass the test requirements $\mathrm{C} 1 \mathrm{C} 2$ pass.

\section{Instrument study consists of Multimedia instrument with frequency Beta and test achievement}

Multimedia instrument teaching with Beta waves are generated by integrating literacy teaching materials involving vowels $(\mathrm{A}, \mathrm{E}, \mathrm{I}, \mathrm{O}, \mathrm{U})$ with the rhythm of the waves frequency $(12 \mathrm{~Hz}$ to $30 \mathrm{~Hz})$ as the background of the power-point throughGarageband Analysis Software and determining the frequency $(12 \mathrm{~Hz}-30 \mathrm{~Hz})$ were analyzed using the Visual EQ. Meanwhile, a tool to measure the achievement of students is from demographic to increase the validity of the study. While the assessments measure the strength of coordination listen and write, which comprises write a letter cited by teachers include 10 points of 5 questions. There are parts of the measure skills and write letters written by the command designated by teachers covering 10 marks of 10 questions and a total score was 20 points, and resource-based (Linus Program, 2014). Time of the assessment carried out in 30 minutes during class hour.

\section{E. Evaluation instruments}

Oral reading test was used to collect data. The test consists of two parts: Part A is the information itself and Part B: Oral Exam Questions read and write. The content of oral questions was extracted from reading literacy screening instruments 4 and 5 of the years 2, 2011. Two sets of tests were used to carry out pre-test and post-test (the contents of both instruments are the same and involved pupils of primary school rehabilitation phase 1 year 1 . Two teachers were trained recovery and has more than five years have revised the questions pre-test and post-test to make sure the questions are in accordance with the turnaround in the ability of the students. Oral test of reading and writing, viewing and writing will be given to the control and administration of minimum marks for literacy reading and writing, viewing and writing are also provided. Teacher is not related to the subjects when treatment is carried out. 
C1C2 Test Set A and Set B C1C2 test is a measurement instrument used to examine the strengths and weaknesses of students in the skills of listening and writing, and writing and elites in promoting master skills Vowels A, E, I, O, and U. his test is used to help teachers identify weaknesses typical recovery and strength faced by the students in the process of listening, reading, writing and reasoning seta devise appropriate teaching program to the students. Items of questions focused on the degree-level knowledge of the difficulties in literacy Vowels letter (A, E, I, O and U) which involves seeing and writing skills as well as listening and writing. (Sariah Amirin, 2014).

\section{F. Pre-test and post test}

Pre exam will be administered before the intervention and post-test will be carried out after the students exposed through frequency Beta power point teaching aids within 6 weeks. Same type of post exam and pre exam which consisting of Literacy Assessment with Look and Writing Vowels are used to test the construct 1 and 2 in literacy construct language Malaysia phase one of year one instead of 3 question. All of the answer should be filled by the student himself. Question one consisted 5 questions and students need to write the answer Vowel read by teacher. The corrected answer will give 2 marks and total corrected answers will score 10 marks. Therefore, questions 2 and 3 consist of 10 blanks and students should write the consonant letter that called for question 2 , while the third question should write the letter assigned by random shows by teachers. The total score is 10 marks for questions 2 and 10 marks for question 3 and all scores will be converted into percentage.

\section{G. Scores Division Literacy skills}

Pre-test and post-test are the same type consists of 3 questions. All answers must be completed by the students themselves. Question one is filled in the blank and students should write the answer read by teacher and each correct answer will be allocated 2 points and the total score is 10 points. Therefore, questions 2 and 3 consist of 10 blanks and students should write a letter consonant called by teachers to question 2, in contrast to the 3 questions students should write the letter assigned by teachers in random way. The total score is 10 points for questions 2 and 10 marks for question 3 and all scores will be converted into percentage.

\section{DATA COLlection Procedures}

This preliminary study is a feasibility study to see Instrument readiness administered in the actual study. In this study, the implementation of a school in the northern state of Perlis who have been involved 34 students of class $1 \mathrm{~K}$ tested with test questions $\mathrm{C} 1 \mathrm{C} 2$ set A. Therefore after it was revealed by the media Video Beta wave power point teaching 3-week, 34 pupils were exposed to simulated wave beta sustainable by teaching media power point to verify the implementation of management control poses in terms of timeliness, clarity of questions and directions of questions, and the certainty of tenure for handling corrugated Beta teaching media and problems arise in the management and treatment operations in order to overcome the Zero defect when it was a real problem in the future interventions.

\section{FINDINGS}

The result of information that is carried on a total of 34 students showed learning difficulties who do not master the language Malaysia literacy focused on literacy and consonant and vowel in Primary School Chinese SJK (C) found that 22 respondents $(64.7 \%)$ have a computer at home and 24 respondents $(70.6 \%)$ agreed and interest in reading through the use of computers and respondents were $24(70.6 \%)$ and 8 respondents $(23.5 \%)$ agreed to follow the teaching using instructional media were simulated by beta waves.

The results to identify whether there is a significant degree of integration needs of Beta-frequency performance to help students master skills Vowel look and write in the language of literacy learning Malaysia a level one year.

Nul Hypothesis: There are differences in the frequency of multimedia effects Beta Sustainable integrated in the control Multimedia learning achievement of pupils see and write a stage Primary School

Research Hypothesis: There is a difference with multimedia effects Frequency Beta Sustainable integrated in the control Multimedia learning achievement of pupils look and write a stage Primary School

TABLE I.

\begin{tabular}{|c|c|c|c|c|c|c|c|c|c|}
\hline \multicolumn{10}{|c|}{ Pairred Differences } \\
\hline & & \multirow[t]{2}{*}{ Mean } & \multirow[t]{2}{*}{$\begin{array}{l}\text { Std. } \\
\text { devia- } \\
\text { tion }\end{array}$} & \multirow[t]{2}{*}{$\begin{array}{l}\text { Std. } \\
\text { error } \\
\text { mean }\end{array}$} & \multicolumn{2}{|c|}{$\begin{array}{c}95 \% \text { Confidence } \\
\text { Interval of the } \\
\text { difference }\end{array}$} & \multirow[t]{2}{*}{$t$} & \multirow[t]{2}{*}{$d f$} & \multirow[t]{2}{*}{$\begin{array}{c}\text { Sig. } \\
2- \\
\text { tailed }\end{array}$} \\
\hline & & & & & Lower & Upper & & & \\
\hline Pair & $\begin{array}{l}\text { Pre-test } \\
\text { listening- } \\
\text { writing } \\
\text { literacy }\end{array}$ & \multirow[t]{2}{*}{18.20588} & \multirow[t]{2}{*}{22.15735} & \multirow[t]{2}{*}{3.79999} & \multirow[t]{2}{*}{25.93701} & \multirow[t]{2}{*}{10.47475} & \multirow[t]{2}{*}{4.791} & \multirow[t]{2}{*}{33} & \multirow[t]{2}{*}{0} \\
\hline & $\begin{array}{l}\text { Posttest } \\
\text { listening- } \\
\text { writing } \\
\text { literacy }\end{array}$ & & & & & & & & \\
\hline
\end{tabular}

A. Statistic Paired Samples T- Test

The results are significant $(\mathrm{t}=-4.791$, $\mathrm{df}=33, \mathrm{P}<0.05)$. Statistic t-test shows that the null hypothesis is rejected and the researchers concluded that there is a difference before and after the effect of using multimedia to the frequency of Beta waves Sustainable affect student achievement in listening skills and writing letters in the language learning Vowel in Year One Level One. The results also showed an overall multimedia need with sustainable Beta frequencies help improve hearing and writing skills by finding the mean descriptive analysis of achievement test scores and seeing-writing Vowel for the pretest is 63.17 points $(63.17 \%)$ of 21 respondents involved and the mean post-test is 81.38 marks $(81.38 \%)$ of 27 respondents involved. The result of the test score achievement seeing and writing letters there is the addition of an achievement test scores in the score $18.21(18.21 \%)$ this means there is an increase of 6 respondents. 
B. The extent to which the implementation of the management of teaching methods Multimedia and Sustainable Beta waves help to overcome learning problems of students in one grade one

In overall, the time taken to take part in the teaching of vocal call is heard and the time 19:16. The view and write is 5.00 seconds listen and write of 36.00 seconds time consuming. The results of this preliminary study found that the total time to recognize Vowel is 1 minute 16 seconds. While in conducting literacy recognize letters were part of hearing call is 34.53 seconds, see and call consonant is $10 \mathrm{sec}$, see and write consonant is 1.26 seconds and the total time taken in handling consonant is 45.79 saan. Thus, the time taken to exposure multimedia teaching beta wave is 2 minutes 17 saat sustainable. Therefore it can be said there is increasing achievement scores obtained by obtaining an average overall score was 65.16 in test set A previous exposed teaching media. Meanwhile, after being exposed to teaching Multimedia Frequency Beta Aids there is a change to 79.78 and the mean score was increased 14.62. This finding indicates that the Multimedia Frequency beta remained there as a positive sign of encouragement and give its findings are positive signs of change on the achievement of the students who were exposed to simulated conserved beta waves.

\section{CONCLUSION}

The preliminary findings of the study it was found appropriate to continue to study the real and the ideal duration for each process of managing and administering the use of multimedia and beta frequency equipment and installation takes place requires students to take 10 minutes, the time of giving the instructions is $2.34 \mathrm{~seconds}$, time exposure operation of teaching and learning to recognize literacy which includes vowel and consonant is only a 2.17 seconds and 15 minutes for the answering and questions session, Set A or Set B. The remaining 5 minutes to the formulation of teaching.

The results of this initial study also showed that Multimedia frequency Beta as a stimulant and gave the difference was significant positive effects before treatment with after treatment to view and write performance in literacy learning for pupils in grade one of primary school.

\section{REFERENCES}

[1] Abdul Rasid Jamian, Norhashimah Hashim dan Shamsudin Othman(2009).Multimedia Interaktif Mempertingkatkan Pembelajaran Kemahiran Membaca Murid-Murid ProBim.Jurnal Pendidikan Bahasa Melayu-JPBM.ISSN:2180-4842.2(2):46-53.

[2] Glesne dan peshkin (1992). Becoming Quqlitative Research. An Introduction. New York: Longman.

[3] Yen T. H.(2013). Pengasuhan Positif: Membesarkan anak-anak dizaman digital. Persatuan Pediatrik Malaysia \&LPPKN.Kesihatan Anak \& Pediatrik. Jid 3:P:33-36.

[4] Campbell, D. T. dan Stanley, J. C.,(1963).Experimental and quasiexperimental designs for research. Dalam N. L. Gage (Ed.), Handbook on research in teaching (halaman 1-80). Chicago:Rand-McNally.

[5] Program Linus (2010). Modul Pengajaran Asas Literasi Asas 1 Program linus. Bahagian Pembangunan Kurikulum, Kementerian Pendidikan Malaysia.

[6] Sabaria Juremi, (2003). Kesan penggunaan kaedah pembelajaran berasaskan masalah dalam meningkatkan kemahiran berfikir kritis, kreatif, kemahiran proses sains dan pencapaian biologi. Tesis doctor falsafah yang tidak diterbitkan, Universiti Sains Malaysia

[7] Sariah Amirin,2014.Pengesahan Intrument K1K2.Presiden Persatuan Dyalexia Malaysia.Kuala Lumpur.sariahamirin@gamil.com.

[8] Gay, L. R. \& Airasan, P. (2003).Education research: Competencies for analysis and application New Jersey: Pearson Education Inc.

[9] Modul Pengajaran Asas Literasi Asas 1 Program LINUS,(2010). Modul pengajaran asas literasi asas 1 program Linus : Program Literasi dan Numerasi Tahap 1 Sekolah Rendah.Bahagian Pembangunan Kurikulum, Kementerian Pendidikan Malaysia.Zainon Kassim Sdn. Bhd.Petaling Jaya, Selongor. 